This item was submitted to Loughborough's Research Repository by the author.

Items in Figshare are protected by copyright, with all rights reserved, unless otherwise indicated.

\title{
An analysis of exports and growth in India: cointegration and causality evidence (1971 - 2001)
}

PLEASE CITE THE PUBLISHED VERSION

LICENCE

CC BY-NC-ND 4.0

\section{REPOSITORY RECORD}

Sharma, Abhijit, and Theodore Panagiotidis. 2019. "An Analysis of Exports and Growth in India: Cointegration and Causality Evidence (1971 - 2001)”. figshare. https://hdl.handle.net/2134/334. 
This item was submitted to Loughborough's Institutional Repository by the author and is made available under the following Creative Commons Licence conditions.

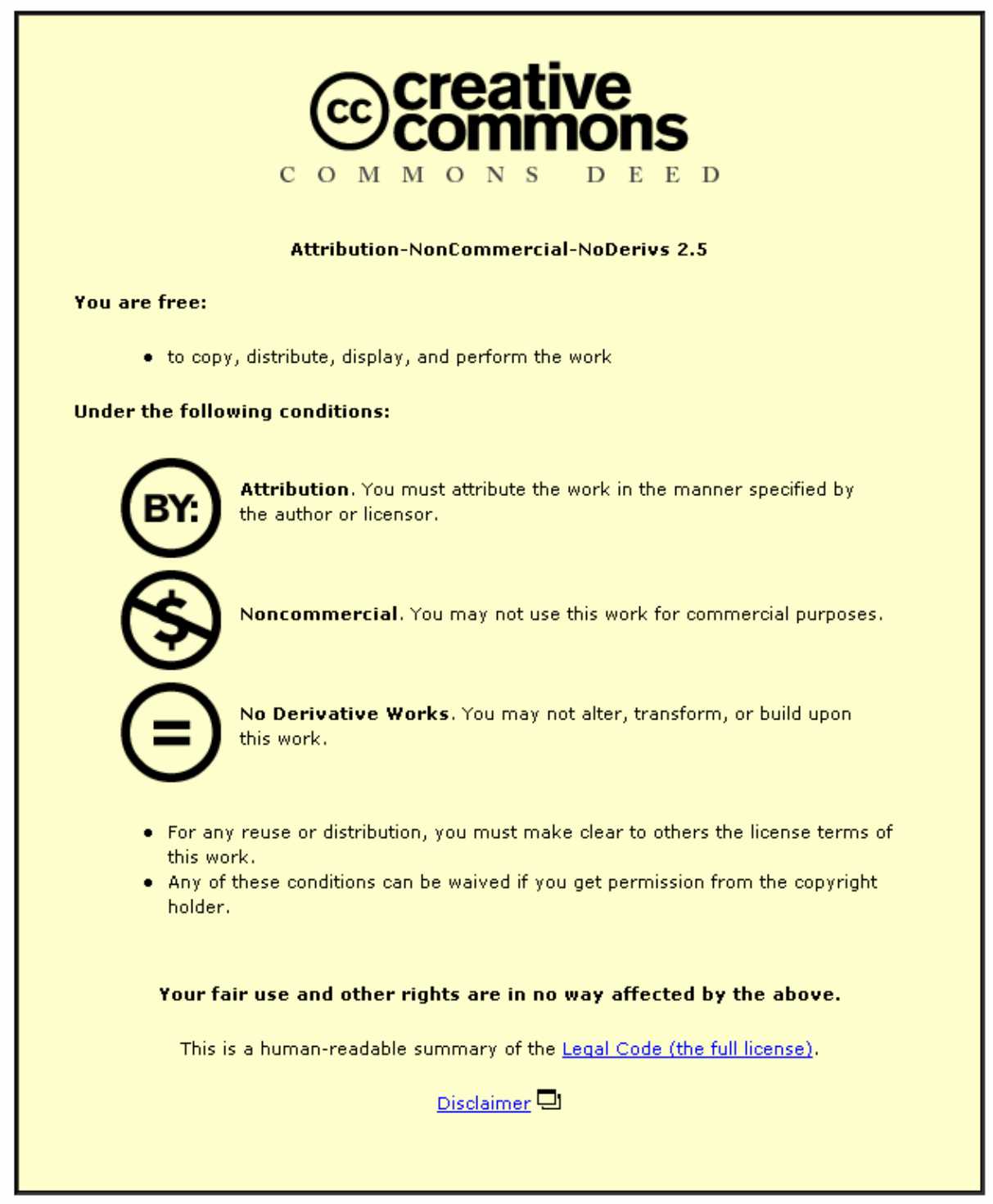

For the full text of this licence, please go to: http://creativecommons.org/licenses/by-nc-nd/2.5/ 


\title{
L Loughborough University
}

This article has been submitted to

Loughborough University's Institutional

Repository by the author.

\section{An Analysis of Exports and Growth in India: Cointegration and Causality Evidence $(1971$ - 2001)*}

Abhijit Sharma $^{\dagger}$ and Theodore Panagiotidis ${ }^{\ddagger}$

March 2004

\begin{abstract}
The relationship between exports and economic growth has been analysed by a number of recent empirical studies. This paper re-examines the sources of growth for the period 19712001 for India. It builds upon Feder's (1982) model to investigate empirically the relationship between export growth and GDP growth (the export led growth hypothesis), using recent data from the Reserve Bank of India, and by focusing on GDP growth and GDP growth net of exports. We investigate the following hypotheses: i) whether exports, imports and GDP are cointegrated using the Johansen approach and Breitung's nonparametric cointegration test, ii) whether export growth Granger causes GDP growth, iii) and whether export growth Granger causes investment. Finally, a VAR is constructed and impulse response functions (IRFs) are employed to investigate the effects of macroeconomic shocks.
\end{abstract}

JEL codes: F17, F21, O53

Keywords: India, exports, growth, cointegration, Granger causality, impulse response functions

${ }^{*}$ We would like to thank two anonymous referees, Mike Dietrich, David Chappell, Costas Milas and Jonathan Perraton for their useful comments. We would also like to thank the participants of the ESRC Seminar Series (Seminar 4), held on 6th Feb 2004 at St Antony's College, Oxford University and the EEFS Annual Conference in Bologna, May 2003 for their feedback. The usual disclaimers apply.

${ }^{\dagger}$ Corresponding author: Abhijit Sharma, Department of Economics, University of Sheffield, 9 Mappin Street, Sheffield S1 4DT, UK. Ph: +44-114-222 3422. Email: A.Sharma@shef.ac.uk

${ }^{\ddagger}$ Department of Economics, Loughborough University, UK. 


\section{An Analysis of Exports and Growth in India: Cointegration and Causality Evidence (1971 - 2001)}

\section{Introduction}

India's experience of colonial rule and Nehru's sympathy for socialist beliefs resulted in a cautious policy environment where self-reliance and indigenous efforts were vigorously encouraged by government. In addition, the grand economic theories ('big push' theories and unbalanced/strategic growth models) attributed variously to Rosenstein-Rodan (1943), Harrod (1939) and Domar (1946) and Hirschmann (1958) led to a dominant role for state in most areas of industrial activity. Nehru's pragmatism and ability to delegate to gifted specialists soon gave way to dogma. During the 1970s and later, influenced by the dependencia school [Prebisch (1970), Frank (1969)], the Indian state eventually developed an intricate body of rules and regulations, which led to a highly protected economy where government departments displayed increasing levels of interventionism in the basic functioning of the economy. The state sector grew, but even so, a large private sector remained extant. The key outcome was that private industry lobbied for and received protection behind tariffs and quota walls, which ultimately undermined the competitiveness of Indian industry in general and led to high-cost inefficient production. This was accompanied by rent seeking behaviour by agents of state [Bhagwati (1982), Krueger (1975), and Srinivasan (1985)]. Inspite of this, India has managed to create a highly diversified industrial base and it has managed to develop competences in a wide range of industrial activities [see Lall (2001)].

India has been described as an 'import substituting country par excellence' [Rodrik (1996: 15)]. A balance of payments crisis in 1991 led to the initiation of an ongoing process of trade liberalisation. These events corrected the in built systemic bias against exports and they have led to a degree of correction of the price distortions in the Indian economy through the creation of a more open economy. More importantly, increased competition and the presence of firms in foreign markets has injected a greater degree of quality consciousness and customer orientation, which had hitherto been largely absent due to the lack of competitive pressures. In the past there were few foreign firms present in the protected domestic market. These changes have reduced the tendency of Indian firms to seek and obtain protection from foreign imports. Policy reform has also reduced the effectiveness of attempts by Indian firms to hide behind high tariff barriers and it has challenged interests that have attempted to perpetuate inefficient production. 
In recent years India's percentage share in world exports has been increasing. Further, there are indications that India is building up new areas of strength in export markets by moving to computer software exports, exports of pharmaceuticals and engineering manufactures in addition to traditional export strengths in gems, jewellery, textiles and primary products [NASSCOM (2002) and DGCIS (various issues)]. These events have succeeded in reducing the ideological opposition to trade which derived in part from India's colonial experience (the dominance of what was a trading company (the British East India Company)), along with a toning down of Nehruvian socialist rhetoric, combined with an obsession with self-sufficiency at any cost.

The purpose of this paper is to investigate the following hypotheses: i) whether exports, imports and GDP are cointegrated using the the Johansen approach and the Breitung's nonparametric cointegration test, ii) whether export growth Granger causes GDP growth, iii) and whether export growth Granger causes investment. Finally, a VAR is constructed and impulse response functions (IRFs) are employed to investigate the effects of macroeconomic shocks. This paper is structured as follows. Section 2 provides a review of previous studies as well as a survey of the work done for the case of India. Section 3 outlines the data sources and provides a description of the specific time series investigated in this study. It also presents in detail the methodology and formal techniques employed in the empirical analysis, as well as the results obtained. Section 4 summarises our main conclusions.

This paper makes a contribution to the existing literature in the following manner. First, most studies that test the export led growth (ELG) hypothesis for India do not tend to cover the post-liberalisation (post-1991) period for more than four or five years at most. This study examines a robust data set for a period of ten years after reform and thus it is better able to capture the effects of liberalisation on exports and output growth. It is thus a more up-to-date test of the ELG hypothesis for India. Secondly, this paper employs the recently developed Breitung's (2002) nonparametric cointegration test, which allows us to circumvent the problem of having to impose arbitrary lag lengths (or estimate deterministic trends) in order to assess the cointegration hypothesis (following the Johansen method), which is a problem almost all the studies in the past have faced. To our knowledge, this nonparametric technique has not been employed previously in empirical tests of the ELG hypothesis, particularly for the case of India. Finally, the VAR that we construct, along with the estimated impulse response functions allow us to simulate the impact of shocks on a given variable and the impact that has on the other variables. These type of 'conceptual experiments' have also not been previously used for the case of India. Additionally, most earlier studies (especially for the case of India) 
tend to rely almost exclusively on the Johansen method. Thus nonparametric cointegration test that we carry out and the use of IRFs significantly strengthen our results as opposed to a simple application of the Johansen technique for empirical analysis.

\section{Literature Review}

\subsection{The Export-Led Growth (ELG) Hypothesis}

There is a large literature on the empirical investigation of the export led growth (ELG) hypothesis, as well as investigations using Granger (1969) causality and the Sims' (1972) method. There is the well known argument about the greater effectiveness of export oriented industrialisation (EOI) [Keesing (1967), Bhagwati (1982), Krueger (1975), and Srinivasan (1985)] as compared to import substituting industrialisation (ISI) [Prebisch (1970); Frank (1969); Myrdal (1957)]. The opposing views on trade as an 'engine' of growth [Lewis (1980)] or a 'handmaiden' of growth [Kravis (1970); Riedel (1984)] are also well known.

There have been several studies that have found some association between exports (or export growth) and output (GDP) levels (or output growth). For the case of developing countries analytical work originally focused on correlations between exports and income [Emery (1967), Maizels (1968), Kravis (1970)], moving on to studies with limited samples [Balassa (1978)], followed by studies focusing on aggregate production functions that included exports as an explanatory variable [Feder (1982)]. There have been studies on the existence of a threshold effect as well [Kavoussi (1984), Moschos (1989), Kohli and Singh (1989)]. These have been supplemented by causality tests [Jung and Marshall (1985); Chow (1987)]. The econometric methods employed in this analysis have been significantly influenced by the work of Granger (1969, 1988), Sims (1972), Engle and Granger (1987), Johansen (1988, 1995), and Johansen and Juselius (1990), among others.

The idea that export growth is one of the major determinants of output growth (viz. the export led growth (ELG) hypothesis) is a recurrent one. Export growth may effect output growth through positive externalities on nonexports, through the creation of more efficient management styles, improved production techniques, increased scale economies, improved allocative efficiency and better ability to generate dynamic comparative advantage. If there are incentives to increase investment and improve technology this would imply a productivity differential in favour of the export sector (in other words, marginal factor productivities are expected to be higher in the export sector than in the other sectors of the economy). It is thus 
argued that an expansion of exports, even at the cost of other sectors, will have a net positive effect on the rest of the economy. It may also ease the foreign exchange constraint. There could also be positive spillover effects on the rest of the economy. These factors notwithstanding, the empirical evidence for the ELG hypothesis is mixed. Time series evidence fails to provide uniform support to the ELG hypothesis whereas a wide body of literature applying a range of cross section type methodologies strongly supports an association between exports and growth. In other words, cross section results appear to find a close and robust relationship, while time series results are less conclusive.

Studies such as Jung and Marshall (1985), Chow (1987), Hsiao (1987), Darrat (1987), Afxentiou and Serletis (1991), Bahmani-Oskooee et al (1991), Dodaro (1991), Greenaway and Sapsford (1994) and Love (1992) have cast some doubt on the validity of the ELG hypothesis. Others such as Serletis (1992), Henrique and Sadorsky (1996), Bahmani-Oskooee and Alse (1993), Ghatak et al (1995) and Nidugala (2001) provide fairly robust evidence in favour of the ELG hypothesis. Most of the time series studies employ the Granger or the Sims' method, while only a few studies combine Granger's test with the Akaike's Information Criterion (AIC) to determine the optimal lag length in the Granger causality test. The latter approach removes the ambiguity involved in the arbitrary choice of lag lengths. Further, most studies (with exceptions like Afxentiou and Serletis (1991) and Bahmani-Oskooee and Alse (1993)) do not consider whether exports and income are themselves cointegrated. Thus there may not exist a genuine long term relationship between exports and output: the results may indicate a pure short run relationship.

\subsection{India's Case}

There are a few studies on this subject for the case of India as well. Dhawan and Biswal (1999) investigate the ELG hypothesis using a vector autoregressive (VAR) model by considering the relationship between real GDP, real exports and terms of trade for India between 1961-93. They employ a multivariate framework using Johansen's cointegration procedure. They find one long-run equilibrium relationship between the three variables and the causal relationship flows from the growth in GDP and terms of trade to the growth in exports. However, they conclude that the causality from exports to GDP appears to be a short run phenomenon. In a similar framework, Asafu-Adjaye et al (1999) consider three variables: exports, real output and imports (for the period 1960-1994). They do not find any evidence of the existence of a causal relationship between these variables for the case of India and no support for the 
ELG hypothesis, which is not too surprising given India's economic history and trade policies. Anwer and Sampath (2001), also find evidence against the ELG hypothesis for India.

In contrast, Nidugala (2001) builds on Esfahani's (1991) model and uses an augmented production function with exports as a regressor. Nidugala finds evidence in support of the ELG hypothesis for the case of India, particularly in the 1980s. He finds that export growth had a significant impact on GDP growth. Further, his study reveals that growth of manufactured exports had a significant positive relationship with GDP growth, while the growth of primary exports had no such influence. Ghatak and Price (1997) test the ELG hypothesis for India for the period 1960-1992, using as regressors a measure of GDP that nets out exports, along with exports and imports as additional variables. Their results indicate that real (aggregate) export growth is Granger-caused by nonexport real GDP growth in India over 1960-92. Their cointegration tests confirm the long run nature of this relationship. However, imports do not appear to be important for the case of India. As corroborated subsequently by Nidugala (2001), their disaggregated analysis shows that nontraditional manufactured exports (such as machinery and transport equipment) are found to Granger cause output growth, while traditional manufactures (such as textiles, wood, paper) have little effect.

\subsection{Excluding growth accounting effects}

In empirical analysis of trade data a major problem arises from the fact that exports are themselves a component of output, via the national income accounting identity [see Michaely (1977, 1979), Heller and Porter (1978), Feder (1982), Afxentiou and Serletis (1991), Love (1992), Esfahani (1991), Greenaway (1994), Ghatak and Price (1997) and Sheehey (1990)]. The results of such a model are likely to suffer from a simultaneity bias since export growth

may itself be a function of the increase in output. To remedy this we use the following method (see also Appendix 1). Following Feder (1982), the economy can be divided into two sectors, export and nonexport. We separate the 'economic' influence of exports on output from that incorporated in the growth accounting relationship by using a measure of GDP (Y) that nets out exports (YX). 


\section{Empirical Analysis}

\subsection{Data Source}

There are two basic sources for data on Indian exports. One set is compiled by the DGCIS (Directorate General of Commercial Intelligence and Statistics), Ministry of Commerce of India and the other is compiled by the Indian central bank, the Reserve Bank of India (RBI). The DGCIS compiles information on real transactions, reporting quantities/ volumes of exports as well as export earnings in Indian rupees. Exports are decomposed into headings congruent with the ITC (HS) ${ }^{1}$ Standard Industrial Classification (SIC) codes. Thus exports are broken down by SIC categories and by destination (i.e. according to the country they are exported to). RBI export data is compiled by aggregating the economy wide financial transactions related to exports, as reported by exporting firms. Exporters and financial intermediaries have to provide this information to the RBI by statute. DGCIS data has been used much more frequently in the literature and the RBI's data has been relatively less frequently referred to. In this study we decided to employ the RBI's data sets for our analysis, in part to correct the above mentioned lacuna. Accordingly, the data used in this exercise has been obtained from the Reserve Bank of India's Handbook of Statistics on the Indian Economy, 2000-012.

The following time series are analysed for the period 1971-2001:

1. Y: GDP (gross domestic product)

2. YX: GDP net of exports

3. RX: real exports (exports deflated by the time series of unit price index of exports)

4. RIM: real imports

5. INV: real gross domestic capital formation (domestic investment) (investments deflated by the GDP deflator)

6. EMP: employment in the formal sector

Constant GDP estimates are used in our study. Exports and investments are deflated using the relevant deflators to permit intertemporal comparisons. (As mentioned, the time series of unit price index of exports is used to deflate the export series, while the GDP deflator

\footnotetext{
${ }^{1}$ International Trade Centre, Harmonised System.

${ }^{2}$ This is posted electronically at www.rbi.org.in.
} 
is used to deflate the time series INV). The prefix ' $L$ ' stands for the natural logarithm of the concerned time series, and ' $\mathrm{D}$ ' denotes differencing of the relevant time series. All econometric estimations in this paper have been carried out using Eviews 4.1, Eviews 5 Beta and EasyReg International.

The data employed in this study are graphically displayed in Appendix 1 (logarithmic transformations of time series data) and Appendix 2 (the first differences of the logarithmic transformations). In all the cases except GDP and GDP without exports, the probability of the Jarque-Berra test statistic provides evidence in favour of the null hypothesis of a normal distribution (these results are available from the authors). Additionally, simple correlations are estimated for the first differences of the series. It is pertinent to note the negative correlations between employment and all economic variables (income, income without exports, real exports and real investment).

\subsection{Unit Roots and Cointegration}

In investigating the export led growth (ELG) hypothesis, the traditional approach of first differencing disregards potentially important equilibrium relationships among the levels of the series to which the hypotheses of economic theory usually apply [Engle and Granger (1987)]. We first test for a unit root. Table 1 summarises the results for unit root tests on levels and in first differences of the data. Strong evidence emerges that all the time series are $I(1)$. In Table $1^{3}$, for the ADF tests, the lag length is based on the Schwarz Information Criterion, while for the PP test bandwidth selection is based on Newey-West.

Following a multivariate approach we proceed with considering the cointegration hypothesis between output (GDP), exports and imports. These variables have been chosen for analysis for three reasons. First, Riezmann et al (1996) have suggested that imports are an important variable while considering causality between exports and growth, and omission of imports could lead to biased results. ${ }^{4}$ Secondly, testing the ELG hypothesis is an explicit objective for us and the chosen variables seem appropriate for such an exercise. Finally, given the set of variables for which time series data is available for India, both investments and employment seem less appropriate. In the case of investments, foreign direct investment is excluded and the series are thus underestimates for total investment in India, especially during the 1990s.

\footnotetext{
${ }^{3} \mathrm{ADF}$ is the Augmented Dickey-Fuller test for unit roots, PP is the Phillips-Perron Unit Root Test.

${ }^{4}$ Inclusion of imports (along with exports and output) in our analysis allows us to examine the notion that imports relieve the foreign exchange constraint that developing countries often face. This referred to as import compression [(Esfahani(1991)].
} 
Table 1: Unit Root Tests

\begin{tabular}{|l|c|c|c|c|}
\hline & \multicolumn{1}{|c|}{$\begin{array}{c}\text { Level } \\
\text { ADF test statistic }\end{array}$} & $\begin{array}{c}\text { Level } \\
\text { PP test statistic }\end{array}$ & $\begin{array}{c}\text { First Difference } \\
\text { ADF test statistic }\end{array}$ & $\begin{array}{c}\text { First Difference } \\
\text { PP test statistic }\end{array}$ \\
\hline $\begin{array}{l}\text { GDP without } \\
\text { Exports }\end{array}$ & 2.997654 & 3.28349 & -6.930733 & -6.073826 \\
\hline Exports & 1.384008 & 1.74475 & -4.170023 & -4.057615 \\
\hline Imports & 0.28261 & 0.411271 & -6.315673 & -6.264815 \\
\hline Investments & 0.307718 & 2.060068 & -6.796392 & -7.717273 \\
\hline $\begin{array}{l}\text { Employment } \\
\text { (Trend and } \\
\text { Intercept) }\end{array}$ & 0.456111 & 2.684556 & -6.098662 & -7.705912 \\
\hline $1 \%$ Critical Value & -3.711457 & -3.67017 & & -3.679322 \\
\hline $\begin{array}{l}1 \% \text { Critical Value } \\
\text { (Trend and }\end{array}$ & -4.296729 & -4.296729 & -4.309824 & -4.309824 \\
Intercept) & & & & \\
\hline
\end{tabular}

Employment data is contested because of definitional issues. More seriously, with a large informal, unorganised sector employment data also suffers from underestimation problems. In our analysis, two cases are considered. First, using the Johansen method, we test whether there is a cointegrating relationship between exports, imports and GDP. Secondly we consider the case of exports, imports and GDP net of exports in order to avoid the 'accounting effect'.

Table 2: Johansen Cointegration Test $[\ln ($ GDP $), \ln ($ Exports), $\ln ($ Imports)]

\begin{tabular}{|c|l|l|c|c|l|c|c|}
\hline $\mathrm{r}$ & Eigenvalue & $\begin{array}{l}\text { Trace } \\
\text { Statistic }\end{array}$ & $5 \%$ CV & Prob* & $\begin{array}{l}\text { Max-Eigen } \\
\text { Statistic }\end{array}$ & $5 \%$ CV & Prob* \\
\hline None & 0.548 & 37.699 & 42.915 & 0.150 & 23.041 & 25.823 & 0.111 \\
At Most 1 & 0.279 & 14.658 & 25.872 & 0.603 & 9.511 & 19.387 & 0.670 \\
At most 2 & 0.162 & 5.147 & 12.518 & 0.575 & 5.147 & 12.518 & 0.575 \\
\hline
\end{tabular}

${ }^{5}$ Mackinnon-Haug-Michelis (1999) p-values.

The results for the first case are presented in Table $2^{6}$. We repeat the test replacing GDP with GDP less exports (Table 3). As Tables 2 and 3 show, we cannot reject the null hypothesis of no cointegration at the $5 \%$ significance level. ${ }^{7}$ The Johansen procedure, like many others, requires

\footnotetext{
${ }^{6} \mathrm{r}$ is the number of cointegration vectors under the null hypothesis. We are assuming a linear deterministic trend. Both the trace test and the max-eigenvalue test indicate no cointegration at both $5 \%$ and $1 \%$ level.

${ }^{7}$ Results for estimations based on the Engle Granger method for exports and output are available from the
} 
Table 3: Johansen Cointegration Test $[\ln ($ GDP less X), $\ln ($ Exports $), \ln ($ Imports)]

\begin{tabular}{|c|l|l|l|l|l|l|l|}
\hline $\mathrm{r}$ & Eigenvalue & $\begin{array}{l}\text { Trace } \\
\text { Statistic }\end{array}$ & $5 \%$ CV & Prob* & $\begin{array}{l}\text { Max-Eigen } \\
\text { Statistic }\end{array}$ & $5 \%$ CV & Prob* \\
\hline None & 0.547 & 37.624 & 42.915 & 0.153 & 22.983 & 25.823 & 0.113 \\
At Most 1 & 0.279 & 14.640 & 25.872 & 0.604 & 9.512 & 19.387 & 0.670 \\
At most 2 & 0.162 & 5.127 & 12.518 & 0.578 & 5.127 & 12.518 & 0.578 \\
\hline
\end{tabular}

estimation of various structural and nuisance parameters. For example, a vector autoregressive (VAR) log order must be specified and then the lag parameters are estimated. To get around this problem we employ the recently developed nonparametric test for cointegration developed by Breitung (2002). In this method, no lag structure or deterministic terms need to be estimated. Breitung's (2002) nonparametric cointegration test is based on the following ideas: let $y(t), t=1, \ldots, n$, be a 2 -dimensional unit root process, such that:

$$
y(t)=y(t-1)+m+u(t)
$$

where $u(t)$ is a zero-mean stationary 2-dimensional time series process, and $m$ is a 2-dimensional vector of drift parameters. If $m=0$ (no drift), let $z(t)$ be the demeaned vector time series $y(t)$, otherwise let $z(t)$ be the detrended vector time series $y(t)$. We compute the following partial sums:

$$
Z(t)=z(1)+z(2)+\ldots+z(t)
$$

and the matrices:

$$
\begin{gathered}
A=Z(1) Z(1)^{\prime}+Z(2) Z(2)^{\prime}+\ldots . .+Z(n) Z(n)^{\prime} \\
B=z(1) z(1)^{\prime}+z(2) z(2)^{\prime}+\ldots . .+z(n) z(n)^{\prime}
\end{gathered}
$$

Let $c(1)$ and $c(2)$ be the increasingly ordered generalized eigenvalues of A with respect to B. If $y(t)$ is cointegrated with cointegration rank $r$ then $\left[n^{2} *(c(1)+\ldots+c(2-r))\right]$ converges in distribution to a function of a standard Wiener process, which is free of nuisance parameters, whereas for $k>2-r,\left[\left(n^{2}\right) * c(k)\right]$ converges to infinity. Therefore, the Breitung test is conducted right-sided, starting with the null hypothesis $r=0$. The cointegration rank $r$ corresponds to the the first accepted null hypothesis. If none is accepted the cointegration

authors. Results are consistent with the conclusions based on the Johansen approach. 
rank is $r=3$, which implies that $y(t)$ is (trend) stationary. Components of $y(t)$ are defined as follows:

$y(t, 1)=L R X$ and $y(t, 2)=L Y$ and $L Y X$, for the given sample size.

Table 4: Breitung's Cointegration Test $[\ln ($ GDP $), \ln ($ Exports), $\ln ($ Imports)]

\begin{tabular}{|c|c|c|c|c|c|}
\hline H0 & H1 & Test statistic & 10\% Critical value & $5 \%$ Critical value & Simulated p-values \\
\hline$r=0$ & $r>0$ & 464.40 & 1158.00 & 1330.00 & 0.903 \\
$r=1$ & $r<1$ & 206.98 & 596.20 & 713.30 & 0.843 \\
$r=2$ & $r<2$ & 44.39 & 222.40 & 281.10 & 0.991 \\
Conclusion & & & $r=0$ & & \\
\hline
\end{tabular}

Table 5: Breitung's Cointegration Test $[\ln ($ GDP less X), $\ln$ (Exports), $\ln ($ Imports)]

\begin{tabular}{|c|c|c|c|c|c|}
\hline H0 & H1 & Test statistic & $10 \%$ Critical value & $5 \%$ Critical value & Simulated p-values \\
\hline$r=0$ & $r>0$ & 464.57 & 1158.00 & 1330.00 & 0.903 \\
$r=1$ & $r<1$ & 207.42 & 596.20 & 713.30 & 0.848 \\
$r=2$ & $r<2$ & 44.37 & 222.40 & 281.10 & 0.991 \\
Conclusion & & & $r=0$ & & \\
\hline
\end{tabular}

In Table 4, we assume that $y(t)$ has a drift and we perform simulations based on 1000 replications of Gaussian random walks with length $n=31$. The conclusion does not alter if this assumption is not made.

Summarising the findings of this section, we find evidence against the hypothesis that exports and GDP are cointegrated and our results question the relevance of the ELG hypothesis for the case of India (see Tables 4 and 5).

\subsection{Granger causality}

To investigate the causality between GDP (and GDP less exports) on the one hand and exports on the other, we perform a simple Granger causality test by estimating the bivariate autoregressive processes for GDP (and GDP less exports) and exports. The objective of this exercise is to test the export led growth (ELG) hypothesis for India empirically. Furthermore, building on our preceding analysis (see Section 2.1), it can be argued that export growth can stimulate investments (gross domestic capital formation), especially if there exists a productivity differential between the export sector and the non-export sector. In such cases, investment 
would be expected to increase in those sectors of the economy where productivity and returns are higher (the export sector). Equally well, it is theoretically plausible to expect the reverse: the case where increased investment would also stimulate export growth. Whether investments are in social overhead capital (infrastructure) or in specific industries, there could be an overall beneficial effect of investments on exports. In Table 8 we empirically test this idea. Thus we have (for $Y$ and $X$ ):

$$
\begin{aligned}
& \Delta y_{t}=a_{0}+a_{1} \Delta y_{t-1}+\ldots+a_{1} \Delta y_{t-1}+b_{1} \Delta x_{t-1}+\ldots+b_{l} x_{t-l} \\
& \Delta x_{t}=a_{0}+a_{1} \Delta x_{t-1}+\ldots+a_{1} \Delta x_{t-1}+b_{1} \Delta y_{t-1}+\ldots+b_{l} y_{t-l}
\end{aligned}
$$

The reported F-statistics are the Wald statistics for the joint hypothesis:

$$
b_{1}=\ldots=b_{l}=0
$$

The null hypothesis is therefore that $\mathrm{X}$ does not Granger-cause $\mathrm{Y}$ in the first regression and that $\mathrm{Y}$ does not Granger-cause $\mathrm{X}$ in the second regression.

Table 6: Granger causality (YX: GDP without exports)

\begin{tabular}{|c|c|c|c|}
\hline Null hypothesis & Obs & F Statistic & Probability \\
\hline DLRX does not Granger Cause DLYX & 29 & 1.1047 & 0.3029 \\
DLYX does not Granger Cause DLRX & 29 & 2.9092 & 0.1000 \\
\hline
\end{tabular}

Table 7: Granger causality (Y: GDP)

\begin{tabular}{|c|c|c|c|}
\hline Null hypothesis & Obs & F Statistic & Probability \\
\hline DLRX does not Granger Cause DLY & 29 & 1.2754 & 0.2691 \\
DLY does not Granger Cause DLRX & 29 & 2.9219 & $\mathbf{0 . 0 9 9 3} *$ \\
\hline
\end{tabular}

Table 8: Granger causality (INV))

\begin{tabular}{|c|c|c|c|}
\hline Null hypothesis & Obs & F Statistic & Probability \\
\hline DLRX does not Granger Cause DLINV & 29 & 0.94789 & 0.33923 \\
DLINV does not Granger Cause DLRX & 29 & 1.06585 & 0.31139 \\
\hline
\end{tabular}


In all the cases in Tables 6, 7 and 8, the reported probabilities are greater than 0.05 and thus no evidence is found to suggest that real exports Granger cause GDP or vice versa (at the $5 \%$ significance level). Since we are using annual observations only one lag is employed. The hypothesis that exports Granger cause investment (or vice versa) can also be rejected. At the $10 \%$ significance level, we could marginally accept the hypothesis that growth in income Granger causes growth in real exports. The evidence in this section does not provide any support for the causality relationship between exports and output (GDP and GDP less exports). There is weak evidence suggesting that the direction of causality runs from GDP to exports, which further strengthens the case against the ELG hypothesis for the case of India.

\subsection{VAR - IRF Analysis}

In order to illustrate the dynamic affects of the impact of unitary shocks on the macroeconomic variables under consideration, we consider the formulation of a VAR (vector autoregressive) model. The first differences of the variables will be employed, since the variables are neither stationary nor cointegrated. A VAR representation is utilised in order to analyse the dynamic impact of random disturbances on the system of variables. The mathematical representation of the VAR we employ can be given by

$$
\Delta y_{t}=A_{1} \Delta y_{t-1}+\ldots+A_{p} \Delta y_{t-p}+B \Delta x_{t}+\varepsilon_{t}
$$

where $y_{t}$ is a $k$ vector of endogenous variables, $x_{t}$ is a vector of exogenous variables, $A_{1}, \ldots, A_{p}$ and $B$ are matrices of coefficients to be estimated, and $\varepsilon_{t}$ is a vector of innovations that may be contemporaneously correlated but are uncorrelated with their own lagged values and uncorrelated with all of the right-hand side variables. The (atheoretical) VAR approach is utilised since it overcomes the need for structural modelling by treating every endogenous variable in the system as a function of the lagged values of all of the endogenous variables in the system. Output, investment and exports are considered to be endogenous and all the other variables exogenous. The preferred model is the one that minimises the AIC and the BIC criteria values (results available from the authors).

Although a general production function could be assumed where GDP growth is a function of the growth in capital and labour force, the drawback of this approach is that VAR systems are not supported by a rigorous framework. However, constructing a VAR model allows us to generate impulse response functions (IRFs). 


\subsection{Impulse Response Functions}

Using the VAR system that has been estimated in the previous section, we extend the analysis and generate impulse response functions. A shock to the $i$ th variable not only directly affects the $i$ th variable but it is also transmitted to all the other endogenous variables through the dynamic (lag) structure of the VAR. An impulse response function (IRF) traces the effect of a one-time shock to one of the innovations on current and future values of the endogenous variables. If the innovations $\varepsilon_{t}$ are contemporaneously uncorrelated, the interpretation of the impulse response is straightforward. The $i$ th innovation $\varepsilon_{i, t}$ is simply a shock to the $i$ th endogenous variable $y_{i, t}$.

The generalised IRF (GIRF) can be defined as

$$
\operatorname{GIRF}\left(n, \varepsilon_{t}, \omega_{t-1}\right)=E\left[y_{t+n} \mid \varepsilon_{j, t}, \omega_{t-1}\right]-E\left[y_{t+n} \mid \varpi_{t-1}\right]_{t}
$$

where $y_{t}$ is a random vector, $\varepsilon_{t+i}$ is a random shock, $\varpi_{t-1}$ a specific realisation of the information set $\Omega_{t-1}$ and $n$ is the forecast horizon. The GIRF is a random variable given by the difference between two conditional expectations which are themselves random variables. We estimate the generalized impulses (GIRF) following Pesaran and Shin (1997). They construct an orthogonal set of innovations that does not depend on the VAR ordering. The generalized impulse responses from an innovation to the $j$ th variable are derived by applying a variable specific Cholesky factor computed with the $j$ th variable at the top of the Cholesky ordering [for more details see Pesaran and Shin (1997)].

It would be important to point out that that IRF analysis can be viewed as a 'conceptual experiment'. We are interested in investigating the consequences of introducing a shock to the system. Appendix 3 presents the results of our IRF analysis. Introducing a positive shock to the GDP, we observe a positive response from both exports and investment which dies out after four periods. In the second graph the shock is introduced to investment. A positive response from GDP is observed which dies out very quickly (after two periods) and a nonsignificant response from exports. Lastly, if the positive shock is introduced on exports, we do get a ('small') positive response from investment and a ('small') negative response from GDP. This reinforces the argument from the previous section for the non-significant role of exports in the growth of the Indian economy.

In this section we have used the notion of IRFs as a conceptual experiment. A one standard deviation (SD) positive shock in real exports elicits a positive response from GDP but this is not 'big' and dies out very quickly. We do not observe any significant responses as a result of 
introducing a shock to the economic system. The non-significant response as a result of the positive shock introduced in exports further reinforces our argument for the non-validity of the ELG hypothesis in the case of India.

\section{Conclusions}

In this study, we test the export led growth (ELG) hypothesis for the case for India using different approaches employing a robust data set. Unlike other studies which test the export led growth (ELG) hypothesis for India covering the post-liberalisation (post-1991) period for about four or five years at most, our study examines data for a period of ten years after reform and thus it is better able to capture the effects of liberalisation on exports and output growth. We thus present a more up-to-date test of the ELG hypothesis for India. By employing Breitung's (2002) nonparametric cointegration test, we are able circumvent the problem of having to impose arbitrary lag lengths (or estimate deterministic trends) in order to assess the cointegration hypothesis (following the Johansen method), which is a problem that studies in the past have also faced. To our knowledge, this nonparametric technique has not been employed previously in empirical tests of the ELG hypothesis, particularly for the case of India.

We investigate the following hypotheses: (i) whether exports, imports and GDP are cointegrated using the Johansen approach, (ii) whether exports and GDP are cointegrated using the Breitung test (iii) whether export growth Granger causes GDP growth, (iv) and whether export growth Granger causes investment. For the first two cases, strong evidence is found against the cointregration hypothesis. Our results contradict the findings of some recent studies on India. Results from the Johansen approach does not negate the results obtained from using the Breitung method. In our analysis, we also fail to find support for the hypothesis that exports Granger cause GDP, using two measures for GDP (GDP with exports and GDP without exports). The same holds for the relationship between exports and investment. Finally, we have utilised the concept of impulse response functions in order to investigate how the system responds to a macroeconomic shock. This approach allows us to simulate the effect of a given (predetermined) shock on the economic system. We conclude that relatively 'big' shocks in real exports do not generate significant responses. This strengthens the argument against the ELG hypothesis for the case of India and strengthens the argument that inspite of reforms, it still retains some characteristics of an import substituting economy.Thus nonpara-

metric cointegration test that we carry out and the use of IRFs significantly strengthen our 
results as opposed to a simple application of the Johansen technique for empirical analysis. Since aggregate export data for India includes sectors such as software exports, the euphoria about perceived successes in the ICT (information and communication technology) sector for India seem somewhat premature, given that at an aggregated level there is little evidence to support the export led growth hypothesis, which brings into doubt the implicitly assumed productivity differentials and resulting positive spillovers into the rest of the economy. 


\section{References}

[1] Afxentiou, P C and A Serletis. (1991), 'Exports and GNP Causality in the Industrial Countries: 19501985', Kyklos, 44, 2, pp. 167-79.

[2] Anwer, M S and R K Sampath. (2001), 'Exports and Economic Growth', Indian Economic Journal, 47, 3, pp. 79-88, paper downloaded from www.indianeconomics.com.

[3] Asafu-Adjaye, J and D Chakraborty. (1999), 'Export-led Growth and Import Compression: Further Time Series Evidence From LDCs', Australian Economic Papers, 38, pp. 164-75.

[4] Bahmani-Oskoee, M and J Alse. (1993), 'Export Growth and Economic Growth: An Application of Cointegration and Error-Correction Modelling', Journal of Development Areas, 27, Jul, pp. 535-42.

[5] Bahmani-Oskoee, M, H Mohtadi and G Shabsigh. (1991), 'Exports, Growth and Causality in LDCs: A Re-examination', Journal of Development Economics, 36, pp. 405-15.

[6] Balassa, B. (1978), 'Exports and Economic Growth: Further Evidence', Journal of Development Economics, 5, pp. 181-89.

[7] Balassa, B. (1985), 'Exports, Policy Choices, and Economic Growth in Developing Countries after the 1973 Oil Shock', Journal of Development Economics, 18, 23-35.

[8] Bhagwati, J. (1982), 'Directly unproductive profit seeking (DUP) activities', Journal of Political Economy, 90, 5, pp. 988-1002.10

[9] Breitung, J. (2002): 'Nonparametric Tests for Unit Roots and Cointegration', Journal of Econometrics, $108,343-364$.

[10] Chow, P C Y. (1987), 'Causality Between Export Growth and Industrial Development: Empirical Evidence from the NICs', Journal of Development Economics, 26, pp. 55-63.

[11] Darrat, Ali F. (1987), 'Are exports and engine of growth? Another look at the evidence', Applied Economics, 19, pp. 277-83.

[12] DGCIS. (various issues), Monthly Statistics of the Foreign Trade of India: Vol I Exports (Annual Number), Directorate General of Commercial Intelligence and Statistics, Ministry of Commerce, Calcutta: Government of India Press.

[13] Dhawan, U and B Biswal. (1999), 'Re-examining export led growth hypothesis: a multivariate cointegration analysis for India', Applied Economics, 31, pp. 525-30.

[14] Dodaro, Santo. (1991), 'Comparative Advantage, Trade and Growth: Export-Led Growth Revisited', World Development, 19, 9, pp. 1153-65.

[15] Domar, E D. (1946), 'Capital Expansion, Rate of Growth and Employment', Econometrica, 14, 2, pp. 137-47.

[16] Engle, R F and C W J Granger. (1987), 'Co-integration and Error Correction: Representation, Estimation and Testing', Econometrica, 55, pp. 251-76.

[17] Engle, R F. (1982), 'Autoregressive Conditional Heteroscedasticity with Estimates of the Variance of United Kingdom Inflation', Econometrica, 50, 4, pp. 987-1008.

[18] Esfahani, H S. (1991), 'Exports, imports, and economic growth in semi-industrialized countries', Journal of Development Economics, 35, pp. 93-116. 
[19] Feder, Gershon. (1982), 'On exports and economic growth', Journal of Development Economics, 12, pp. 59-73.

[20] Frank, Andre Gunder. (1969), Latin America: Underdevelopment or Revolution?, New York: Monthly Review Press.

[21] Fuller, W A. (1976), Introduction to Statistical Time Series, New York: John Wiley and Sons.

[22] Ghatak, S and S W Price. (1997), 'Export Composition and Economic Growth: Cointegration and Causality Evidence for India', Weltwirtschaftliches Archiv, 133, 3, pp. 538-53.

[23] Granger, C W J. (1969), 'Investigating Causal Relationships by Econometric Models and Cross-spectral Methods', Econometrica, 37, 3, pp. 424-38.

[24] Granger, C W J. (1988), 'Some Recent Developments in a Concept of Causality', Journal of Econometrics, 39, pp. 199-211.

[25] Greenaway, D and D Sapsford. (1994), 'What does Liberalisation do for Exports and Growth', Weltwirtschaftliches Archiv, 130, 1, pp. 152-74.

[26] Harris, R and Sollis, R. (2003), Applied Time Series Modelling and Forecasting, New York: Wiley.

[27] Harrod, R F. (1939), 'An Essay in Dynamic Theory', Economic Journal, 49, 193, pp. 1-33.

[28] Heller, P S and R C Porter. (1978), 'Exports and Growth: An empirical re-investigation', Journal of Development Economics, 5, 2, pp. 191-93.

[29] Henriques, I and P Sadorsky. (1996), 'Export-led growth or growth-driven exports? The Canadian case', Canadian Journal of Economics, 29, 3, pp. 540-55.

[30] Hirschmann, A O. (1958), The Strategy of Economic Development, New Haven: Yale University Press.

[31] Hsiao, M C W. (1987), 'Tests of Causality and Exogeneity between Exports and Economic Growth: The Case of Asian NICs', Journal of Economic Development, 12, 2, pp. 143-59.

[32] Johansen, S. (1988), 'Statistical Analysis of Cointegration Vectors', Journal of Economic Dynamics and Control, 12, pp. 231-54.

[33] Johansen, S. (1995), Likelihood-Based Inference in Cointegrated Vector Autoregressive Models, Oxford University Press, Oxford.

[34] Johansen, S and K Juselius. (1990), 'Maximum Likelihood Estimation and Inference on Cointegration With Applications for the Demand for Money', Oxford Bulletin of Economics and Statistics, 52, 2, pp. 169-210.

[35] Jung, W S and P J Marshall. (1985), 'Exports, Growth and Causality in Developing Countries', Journal of Development Economics, 18, pp. 1-12.

[36] Kavoussi, R M. (1984), 'Export Expansion and Economic Growth: Further Empirical Evidence', Journal of Development Economics, 14, pp. 241-50.

[37] Kohli, I and N Singh. (1989), 'Exports and Growth: Critical Minimum Effort and Diminishing Returns', Journal of Development Economics, 30, pp. 391-400.

[38] Krueger, A O. (1975), The Benefits and Costs of Import Substitution in India: A Microeconomic Study, Minneapolis : University of Minnesota Press.

[39] Lall, Sanjaya. (2001), Competitiveness, Technology and Skills, Cheltanham: Edward Elgar. 
[40] Love, J. (1992), 'Export Instability and the Domestic Economy: Questions of Causality', Journal of Development Studies, 28, 4, pp. 735-42.

[41] MacKinnon, J G, A A Haug, and L Michelis (1999) 'Numerical distribution functions of likelihood ratio tests for cointegration', Journal of Applied Econometrics, 14, pp. 563-577.

[42] Michaely, M. (1979), 'Exports and Growth: A Reply', Journal of Development Economics, 6, pp. 141-43.

[43] Michaely, Michael. (1977), 'Exports and Growth: An Empirical Investigation', Journal of Development Economics, 4, pp. 49-53.

[44] Moschos, D. (1989), 'Export Expansion, Growth and the Level of Economic Development: An Empirical Analysis', Journal of Development Economics, 30, pp. 93-102.

[45] NASSCOM. (2002), Statistics of the Indian IT Industry (online), (downloaded from www.nasscom.org), New Delhi: National Association of Software and Service Companies.

[46] Nidugala, G K. (2001), 'Exports and Economic Growth in India: An Empirical Investigation', Indian Economic Journal, 47, 3, pp. 67-78, paper downloaded from www.indianeconomics.com.

[47] Pesaran, H and Y Shin. (1997), 'Generalized impulse response analysis in linear multivariate models', Economics Letters, 58, pp. 17-29.

[48] Prebisch, R. (1970), 'Towards a New Trade Policy for Development', report by the Secretary General of UNCTAD, United Nations, 1964. Reprinted in G.M. Meier, Leading Issues in Economic Development: Studies in international poverty, Second Edition, New York: Oxford University Press.

[49] Reserve Bank of India (2001), Handbook of Statistics of the Indian Economy, 2000-01, downloaded from www.rbi.org.in, New Delhi: RBI.

[50] Riezman, R, Whiteman C H and P M Summers. (1996), 'The Engine of Growth or Its Handmaiden? A Time-Series Assessment of Export-Led Growth', Empirical Economics, 21, pp. 77-110.

[51] Rodrik, Dani. (1996), 'Understanding economic policy reform', Journal of Economic Literature, 34, pp. $9-41$.

[52] Rosenstein-Rodan, P N. (1943), 'Problems of Industrialisation of Eastern and South-Eastern Europe', Economic Journal, 53, June-Sept, pp. 202-11.

[53] Serletis, Apostolos. (1992), 'Export growth and Canadian economic development', Journal of Development Economics, 38, pp. 133-45.

[54] Sheehey, E J. (1990), 'Exports and Growth: A Flawed Framework', Journal of Development Studies, 27, pp. 111-16.

[55] Sims, C A. (1972), 'Money, Income and Causality', American Economic Review, 62, 4, pp. 540-52.

[56] Srinivasan, T N. (1985), 'Neoclassical Political Economy, the State and Economic Development', Asian Development Review, 3, 4, pp. 38-58. 


\section{Appendix 1: Feder's (1982) Approach}

Following Feder (1982), the economy can be divided into two sectors, export and nonexport. We separate the 'economic influence' of exports on output from that incorporated in the 'growth accounting' relationship by using a measure of GDP (Y) that nets out exports (YX). More formally, consider the following simple model:

$$
\dot{Y}=a_{0}+a_{1} \dot{X}+u
$$

where dots denote proportional rates of change and Y stands for GDP while X stands for exports. Then define $\mathrm{N}=\mathrm{Y}-\mathrm{X}=\mathrm{YX}=\mathrm{GDP}$ net of exports.

Also $\dot{Y} \equiv \alpha \dot{X}+(1-\alpha) \dot{N}$ where $\alpha=\mathrm{X} / \mathrm{Y}$ and $(1-\alpha)=\mathrm{N} / \mathrm{Y}$.

By substitution we obtain

$$
(1-\alpha)=a_{0}+b \dot{X}+u ; b=\left(a_{1}-\alpha\right)
$$

Thus $b$ provides an estimate of the 'economic effect' as opposed to the sum of the accounting and economic effect obtained from $a_{1}$ in (1). In general we can state

$$
(1-\alpha) \dot{\mathrm{N}}=\mathrm{a}_{0}+\mathrm{b} \dot{\mathrm{X}}+\mathrm{cZ}+\mathrm{u}
$$

where $\mathrm{Z}$ is the vector of additional determinants of $\dot{Y}$. 


\section{Appendix 2: First Differences of Time Series}

Figure 1: First Differences of Series
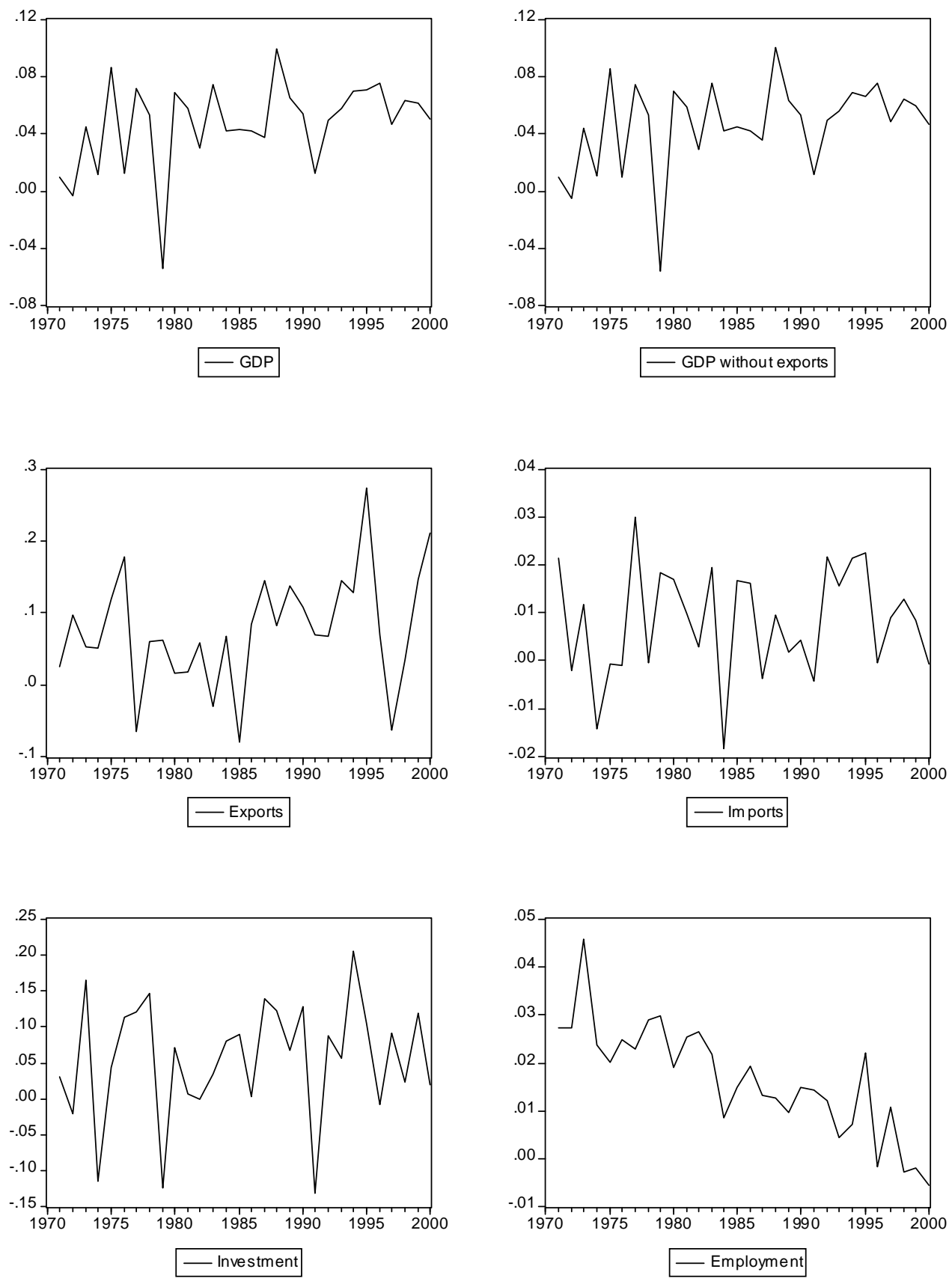


\section{Appendix 3: IRFs}

Figure 2: Impulse Response Functions

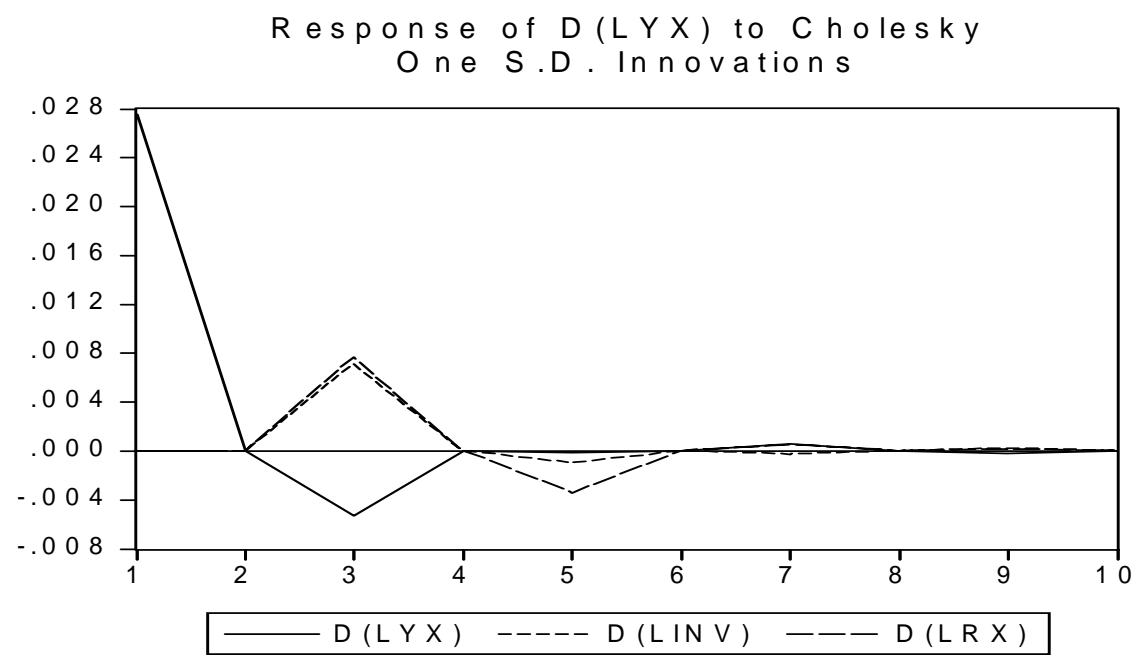

Response of D ( LINV) to Cholesky

O ne S.D. Innovations

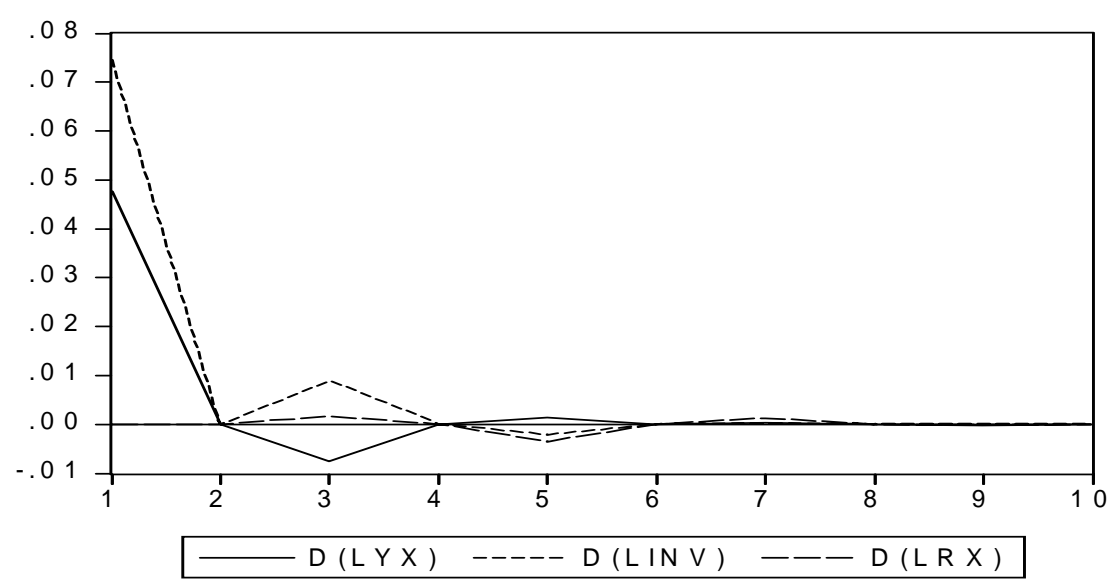

R esponse of $D(L R X)$ to $C$ holesky

O ne S.D. In novations

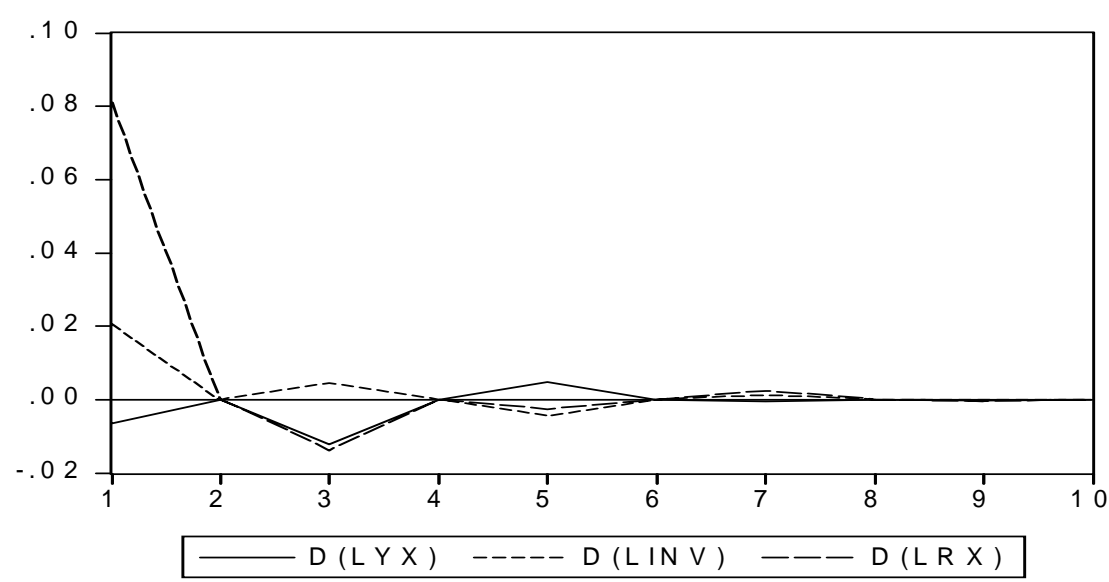

